\title{
DEFENCE INFRASTRUCTURE - AN ATTEMPT AT IDENTIFICATION
}

\author{
Lt. Col. Piotr KRZYKOWSKI, PhD Eng \\ War Studies University, Warsaw, Poland \\ p.krzykowski@akademia.mil.pl
}

\begin{abstract}
Security and infrastructure are two closely related terms, which is why they are so often referred to at the same time. In today's world, infrastructure is essential to ensure broadly understood security, and a lack of security will not fulfil its basic role.

Today, identified threats and challenges to national security, and thus to the security of the state, evoke the need to participate in preparing all components of the defence system of the state. The management of state defence is a very complex process, requiring a properly prepared system to function reliably in times of peace, but also in times of crisis and war. Its role is to integrate individual elements of the defence system into a uniform and efficient whole.

Effective defence activities and ensuring the security of its citizens and all its assets are the core activities of the state. The defence area of the state is now comprehensive in nature and is of interest to the entire apparatus of state power.

The aim of the article is to present the role of the defence infrastructure in the life of the state, its relation to national security and an attempt to identify the defence infrastructure of the state, taking into account the key state infrastructure.
\end{abstract}

Keywords: defence, safety, infrastructure, security 


\section{Introduction}

One of the most important needs of every human being, but also the basis for the proper functioning of every state, is to ensure security. Security is a fundamental value that is esteemed by an individual, a nation and the wider international community. Security is about satisfying the need for survival, stability, development, balance, prosperity, and happiness (Stańczyk 1996, p. 9).

The term "security" is a notion often used and encountered in everyday life, and in the organisation and functioning of the state, society and science. Due to the widespread use of the definition, adjectives (personal, public, national) are added to assist the concept of security (Jakubczak 2003, p. 58).

Similarly, the word infrastructure has become commonplace. Although the term is often overused, everyone assumes that it refers to a system of devices, activities and institutions that support certain tasks, either directly or indirectly.

Security and infrastructure are two closely related terms, which is why they are so often talked about at the same time. In today's world, infrastructure is essential to ensure broadly understood security. Therefore, in its nature, the infrastructure that can be used for defensive purposes is all of the facilities, installations and institutions that ensure their technical efficiency and maintenance, which is the basis for the functioning of the state security system.

Today, identified threats and challenges to national security, and thus to the defence of the state, result in the need to participate in defence preparations encompassing all the components of a state defence system. The management of state defence is a very complex process, requiring a properly prepared system, functioning reliably in times of peace, but also in times of crisis and war. Its role is to integrate various elements of a defence system into a uniform and efficient whole.

Nowadays, state security is one of the fundamental directions of its activity related to country development, both in times of peace and during war. These activities, in turn, constitute the state's ability to carry out effective defensive actions and to ensure the protection of its citizens and all its assets. The field of state defence is 
now comprehensive and is of interest to the entire apparatus of state authority, public administration and the state economy.

Therefore, to maintain the comprehensive nature of the state's activities in the sphere of security, it is necessary to properly define the defence infrastructure. What is it today and to what does it refer? It ought to be established whether the defence infrastructure is: military infrastructure, civil defence infrastructure or critical infrastructure? Are there elements selected for their possible use in the state security system in this entire spectrum of infrastructure?

The subject of the author's research is to try to identify defence infrastructure in relation to the strategic, key, critical or protective infrastructure existing in Poland. The article is, at the same time, an attempt to prove - through a critical analysis of the literature on the subject and legal acts - that defensive infrastructure underlies the national security of the Republic of Poland.

\section{Defence system, a general perspective}

The state defence system is not a currently isolated, independent state structure. Economic and defence tasks are defined in the powers of all state authorities and privatised economic entities, which play a special role in the state defence system.

Therefore, the system of state defence is based primarily on the national defensive potential including the possession of the appropriate forces and means to perform necessary tasks in the field of defence and proper preparation of the social, economic and logistic infrastructure to support state defence.

Due to the complexity and breadth of this area of activity, one of the determinants deciding on the effectiveness of defensive preparations is familiarity with the scope of defence tasks. Therefore, right at the beginning of a discussion on the defence system of the Republic of Poland, one should confront several basic concepts used in the common sense.

Until the end of the 20th century, we had used the term "defence system of the Republic of Poland" in our research and teaching activities. In 2000, the terms 
the "system for defending the Republic of Poland" and the "security system of the Republic of Poland" appeared. Currently, the dominant role is performed by a wider concept of the "national security system of the Republic of Poland", encompassing "national defence".

It is, therefore, relatively difficult for a random citizen to understand what is important in order to secure the most crucial interests of a nation: whether it is national defence, the defence system or the security system. However, it is certain that the most important thing is the national (state) security system. This system was defined as an internally coordinated set of organisational, human and material elements aimed at counteracting all threats to the state, in particular political, economic, psychosocial, environmental and military ones (Pawłowski 2009, p. 140).

However, as the National Security Strategy of the Republic of Poland states, the system consists of the forces, means and resources allocated by the state to the implementation of tasks in this area, appropriately organised, maintained and prepared. This system is based on the management and executive subsystems: operational (defence and security) and support (social and economic). Its important elements are the armed forces, government services and institutions obliged to prevent and counteract external threats, ensure public safety, carry out rescue operations and protect the population and property in emergency situations, as well as - to the extent provided for in the Polish Constitution and relevant laws local government and other legal entities, including entities building the defence potential (SBN RP 2014, pp.13-15).

Therefore, in systemic terms, national security is the entire preparation of the state for the continuous creation of national security, including the basic elements, such as

- the legal basis of security;

- national security policy and strategy;

- civil and military organisation for national protection and defence;

- security infrastructure;

- education for security;

- international alliances and cooperation on security (Marczak 2006, p. 22). 
As stems from these concepts, the national security system is aimed at counteracting all threats. Therefore, the basis of the structure of national security is both a civil and a military organisation of national security and defence as an element of national security, which constitutes a certain defence system of the state. This system is an internally coordinated set of elements of the overarching control subsystem and detailed functional executive subsystems, defined by interaction and substitution relations, serving the protection and defence of vital national security interests - security of the state as a public institution and security of society (Kitler 2002, p. 243).

The efficient and reliable functioning of such a system relies, to a large extent, on implementation of a heterogeneous range of defence and security tasks and undertakings by both government administration bodies and local government bodies preparing to operate in the conditions of an external threat to state security and during war (Wojnarowski 2013, p. 9).

According to Jan Wojnarowski, the state defence system should have four principal capabilities of the state's activity (Wojnarowski 2013, p. 10):

1) the political, social and economic ability, which refers to all the forces and means (physical and mental) of a nation taking an active part in the creation of a defence system of the state;

2) the ability to monitor and prevent risks and to react in advance to emerging challenges, using the powers, skills and knowledge of those involved in the operations of specific subsystems;

3) the ability to cooperate with allied structures: the military (army) potential, as with its defence specialisation, is to adequately prepare the armed forces to conduct their defence activities in accordance with Article 5 of the Washington Treaty and to defend the sovereignty and independence of the state, in accordance with Article 3 of that Treaty;

4) the ability to deter, protect and defend the state, which should ensure favourable conditions for performance of defence tasks by authorities, public administrations and business entities, and create appropriate conditions for protection of property and maintenance of law and order, as well as for performance of collective defence tasks.

Today, the defence of the state is one of the fundamental directions of its activity related to the development of the state both in times of peace and in times of 
war. It is the ability of the state to carry out effective defensive actions, protect its citizens and all its assets. The field of state defence is now comprehensive and is of interest to the entire apparatus of state authority, public administration and the state economy. Therefore, the defence system of the state, both functionally and organisationally, should be viewed from the perspective of the mission, objectives, tasks and functions performed by the state to ensure national security.

The effectiveness of the state defence system depends on the quality of its operational planning and defence programming, its defence preparations in peacetime and in all of its components, including:

- law-making;

- ensuring operational reliability;

- development of the defence potential of the state;

- preparing the armed forces, government administration bodies and local government bodies to operate in conditions of external threat to state security and during war,

- maintenance of the material base.

The state defence system is currently the most perfect form of organisation of a country for the purpose of carrying out national security objectives; therefore, a proper understanding of the scope of operation and organisation of the Defence System of the Republic of Poland is the decisive factor in defining defence tasks of the operational subsystem. This subsystem has defence and protection elements, among which the priority issues include optimal development (organisational, technical, training) of all institutions responsible for civil protection, public security and crisis management (Biała Księga RP 2013, p.224), including defensive targeting of the development of technical and economic infrastructure within the national economy, or the creation and maintenance of the state defence infrastructure.

\section{What is the (defence) infrastructure and what is its nature? Identification of (defence) infrastructure}

In the reality of today, we deal with numerous liberal uses in defining and alternating the use of the words defence and security, and yet these two words 
etymologically describe something completely different. Security (Dunaj 1996, p. 646) is a shelter, a haven, protection against something unfavourable, bad or dangerous. In turn, defence (Dunaj 1996, pp. 638-639) usually means repelling aggression, attacking someone or something, resisting an attacking enemy, usually with the use of weaponry and appropriate equipment.

Similarly, the definition of infrastructure is overused quite freely. It is true that we are aware of the importance of infrastructure and the consequences of its disruption for national security, and yet we do not fully know the meaning of this word.

When looking for an answer to what a defence infrastructure is, it is important to start by clarifying the general concept of "infrastructure". In the Polish language dictionary, the term is defined as a system of devices, activities and institutions that support, directly or indirectly, the productive zone of the economy (including construction, transport, energy, communications), and those that are the necessary base for the proper functioning of society (such as education, administration, health care, banking, security authorities) (Dunaj 1996, p. 322). A very similar definition of infrastructure can be found in many other studies in the form of lexicons or manuals. They clearly distinguish between two aspects of the concept - economic and social. This is confirmed by the scientific and technical lexicon, which states that: "Infrastructure is the basic equipment and institutions necessary for the proper functioning of both economic sectors (technical infrastructure) and society as a whole (social infrastructure, providing services in the spheres of law, security, education, health care, etc...)". (Czerni 1984, p. 306). The encyclopaedia, on the other hand, provides a definition of infrastructure as the whole encompassing the basic equipment and institutions necessary for the proper functioning of the economy (Lesław 1974, p. 293). To complement the dictionary meaning of the term "infrastructure", the NATO definition in AAP-6 PL (2014) needs to be cited, which refers to permanent buildings, facilities and other fixed installations required to support military capabilities (AAP-6 2014, p. 213).

It can be assumed that the terms given are clear, yet the concept of "infrastructure", although it has been used for years in Poland, does not have a generally accepted definition to this day, and thus it is not clearly understood. The reason for this state of affairs, which practically makes it impossible to carry out any precise analyses of development, or to compare the interbranch or international degree and rate of 
development of infrastructure, its capital intensity, effectiveness of investments, etc., is, first of all, the vague character of the definitions, which allows for quite arbitrary interpretation" (Wojewódzka-Król 1999, p. 11). Therefore, in our legal system, infrastructure is freely defined as critical / social / technical / transport / road / sea / hydro-technical / inland / aviation / tourist / logistic / research.

The above definitions of infrastructure reflect the essence of the concept. It clearly stems from them that this term is used to describe basic devices, enterprises and institutions providing services useful or directly necessary for the functioning of production departments of the state economy.

Therefore, in the reference books, the term "infrastructure" is often connected with the issues of the functioning of the state or the economy. Hence, the term "state infrastructure" is defined as "a part of infrastructure which includes facilities, fixed devices and service institutions necessary for the proper functioning of productive sectors of economy and life (including safety) of the country's population". (Pawłowski 2002, p. 45). This reveals a very important feature of the infrastructure - its various functions, interconnectedness and interdependence that make it possible to conclude that, in general, no infrastructure can exist on its own.

Different understanding of the concepts of "state infrastructure" and "social and economic infrastructure" by the researchers of the problem boils down to a consensual conclusion as to its enormous significance for the economic development of the country, care for the already possessed infrastructure and for its expansion (Kaczmarski 2010, p. 16).

The mere explanation of the definition of infrastructure does not yet provide the certainty that would allow an understanding of the essence of defence (strategic) infrastructure for a given country. The question arises as to what infrastructure can be considered a priority, which infrastructure systems and facilities are of strategic importance for the functioning of the state and its society, what infrastructure can be called defensive?

Or maybe, as R. Radziejewski called it, these are the facilities which, due to their great importance, must be subject to special protection organised at the central level, suggesting, at the same time, that these are the facilities and devices subject to mandatory (Journal of Laws No. 114, item 740) and special protection (Journal 
of Laws No. 116, item 1090) and real estate considered necessary for the purposes of state defence and security (Journal of Laws No. 207, item 2107). He classifies these buildings and real estate as key state infrastructure (Fig. 1). (Radziejewski 2013, p. 261)

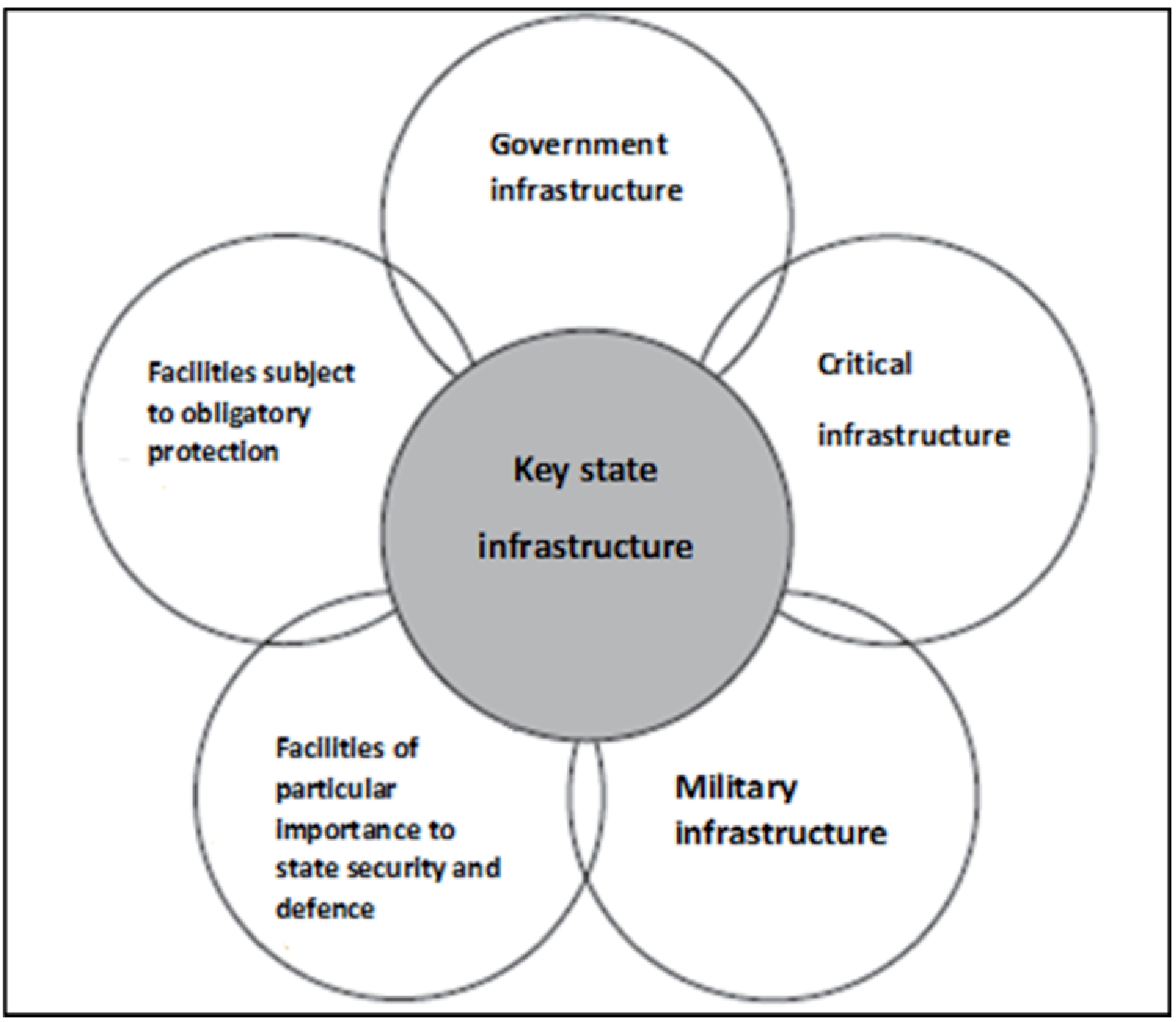

Fig. 1. Key State Infrastructure. Source: (Radziejewski 2013, p. 261)

Infrastructure has recently been subject to a great deal of discussion in the context of critical infrastructure. It is indeed this kind of infrastructure that plays an important role in ensuring security in a broad sense and in a multifaceted way, from the individual links, such as a citizen, and ending up with the state.

Initially, the term "critical infrastructure" was associated with the concept "defence infrastructure" (Jankowski 2005, pp. 109-117; Wiśniewski 2006, pp. 101-108). The outlook on the problem resulted mainly from the perception of the critical 
infrastructure from the perspective of ongoing or planned military actions aimed at blitz incapacitation of an enemy by damaging or destroying sensitive points (centres).

At present, the Polish legal system precisely defines the critical infrastructure, which should be understood as the systems and their functionally connected facilities, including construction facilities, devices, installations, services essential for the security of the state and its citizens and serving to ensure efficient functioning of public administration bodies, as well as institutions and entrepreneurs (Journal of Laws of 2007, No. 89, item 590, as amended). If we consider the systems included within critical infrastructure, i.e. (Dziubańska-Wójcik 2016, p 176, 280):

a) supply of energy, raw materials and fuels;

b) communications;

c) ITC networks;

d) Financial;

e) the supply of food;

f) water supply;

g) health protection;

h) transport;

i) rescue;

j) ensuring the continuity of public administration operations;

k) production, storage, retaining and use of chemical and radioactive substances, including pipelines for hazardous substances;

and by analysing the features ${ }^{1}$ that determined the distinction and joint treatment of this particular area of the economy, it can be concluded that we are dealing with security infrastructure.

This approach is supported by a further provision in the aforementioned Crisis Management $\mathrm{Act}^{2}$ concerning the protection of critical infrastructure. This is in line with the conviction that today most researchers of the issue perceive critical

1 These characteristics can be considered in technical, economic and organisational aspects.

2 critical infrastructure protection - means all activities aimed at ensuring the functionality, continuity and integrity of critical infrastructure in order to prevent, mitigate and neutralise threats, risks or vulnerabilities and to restore this infrastructure swiftly in the event of a failure, attack or other disruptive event. 
infrastructure as assets, services and systems that support the economic, political and social life of a country, the importance of which is such that their total or partial destruction or threat could (Atlas 2008, p. 119):

- cause massive loss of life;

- have a serious impact on the country's economy;

- have other serious social consequences for the lives of citizens;

- pose a direct problem to central government.

The recognition of critical infrastructure as being either non-defensive, and barely, or even, having security characteristics, is complemented by an interpretation given in the Polish National Security Strategy of 2014. It indicates the importance of ensuring the conditions for securing the critical infrastructure (SBN RP 2014, Chapter III). It underlined that securing the critical infrastructure is the responsibility of operators and owners, who are supported by the capacity vested in public administrations.

As it has already been pointed out, the critical infrastructure is characterised by extremely complex, heterogeneous and independent sets (groupings) of facilities, systems and functions that are vulnerable to a variety of threats. Given the size and scope of the potential objective, it cannot be assumed that all critical infrastructure components can be fully and completely protected against possible threats. For this reason, it has been assumed that the protection of critical infrastructure should be an important element of the state security policy and the uniform system, and should be considered a priority task assigned to the government administration as well as to other entities performing tasks to guarantee national security. State actions are based on the possible activation of a crisis management system in the event of disruption of the critical infrastructure, as well as on raising awareness, knowledge and competence and promoting cooperation in the scope of the importance of the critical infrastructure to ensure the efficient functioning of the state and methods to protect it.

It follows from the above that activities related to critical infrastructure protection fit into the concept of strategic activities of protective activities operational strategy, as well as the preparation strategy and security subsystem (SBN RP 2014).

Against this background, one may ask: what are the security structures and are they still there at all? The answer to this question can be found in documents 
and analyses of the National Civil Defence (Maliński Kwiatkowski 2011, pp. 362-368), in which the listed facilities were described as shelters and hiding places. Therefore, security structures are those designed to protect the citizen and are the responsibility of the Head of Civil Defence of the country.

Security structures are classified as facilities that meet the requirements of collective protection of the population against weapons of destruction, radioactive and chemical contamination, including toxic industrial substances. At the same time, security structures, in addition to protecting people, can be prepared for concealment and protection against damage to chattels of cultural value, particularly important documentation, valuable instruments and stocks of food and medicine. These types of buildings can be used more extensively. Both shelters and hiding places are prepared during peacetime, except that the latter are only partly prepared during peacetime (without deploying any specialised installations or equipment) and are brought to technical readiness when a threat occurs. They may not be put into service until a certain time has elapsed since the higher defence states in the country have been introduced. Polish regulations stipulate that security structures may be prepared as shelters with a specified structural strength and as hiding places without any special strength requirements.

It is important to note that the lack of clear legal regulations concerning security structures has a significant impact on the process of creating new structures that meet the criteria of security structures and their maintenance.

It should be noted that the owners of shelters and hiding places have an obligation to ensure generally binding requirements with respect to the maintenance of construction facilities, in particular those specified in the provisions of the Act on Construction Law of 7 July 1994. (Journal of Laws of 1994 No. 89, item 414, as amended). Since, according to Article 5(1) of the aforementioned law, a construction facility together with its associated construction equipment must, in view of its expected useful life, be designed and constructed in the manner laid down in the regulations, including technical and construction regulations ${ }^{3}$, and in accordance with the principles of technical know-how, ensuring civil protection,

3 Rules stipulated under Articles7 and 8 of the construction law, Journal of Laws of 1994, No. 89 , item 414 , as amended. 
in accordance with the requirements of civil protection laid down in separate provisions.

At present, no Polish legal document defines the tasks of civil protection in detail. Until July 9, 2002, these tasks were laid down in the Regulation of the Council of Ministers on Civil Protection (Journal of Laws of 1993, No. 93, item 429). This act specified the detailed scope of activities of the Head of Civil Defence of the Republic of Poland, as well as the manner of coordinating the preparation and implementation of civil protection projects. It indicated the person responsible for defining the requirements of security and utility structures and the rules of their use. However, this regulation was replaced by the Regulation of the Council of Ministers on the detailed scope of activities of the Head of Civil Defence of the Republic of Poland, heads of civil protection of voivodeships, districts and municipalities (Journal of Laws of 2002, No. 96, item 850), which did not specify the general tasks of civil protection, as well as requirements for security and utility structures, but regulated the detailed scope of activities of the Head of the Civil Defence of the Republic of Poland, heads of civil protection of voivodeships, districts and municipalities.

It is worth pointing out here that the security structures in Poland were recently taken care of in 1995, when, on the order of the Head of Civil Defence of the country, the municipalities were ordered to reserve shelters when carrying out their spatial development plans ${ }^{4}$.

It is in the Act of 27 March 2003 on spatial planning and development that issues related to state security and spatial planning are included (Journal of Laws of 2016, item 778). It should be noted that according to the interpretation of Article 16(3) of the aforementioned Act, there was a Regulation of the Minister of Infrastructure of 7 May 2004 on the method for taking into account the needs of state defence and security in spatial planning (Journal of Laws of 2004, No. 125, item 1309),

4 According to the information contained in the civil defence plans, in the chapter on the logistic security of civil defence operations, the table entitled "Complements to security structures" specifies the possibility of achieving the operational readiness of security structures partly prepared after 2 days (applies to ready-made structures which are in operation readiness, but are rented e.g. as warehouses; the lessor is obliged to put them into use within 48 hours). The period of one or two quarters applies to partly prepared buildings, e.g. cellars in multi-storey residential buildings or large-size commercial buildings, which require work in order to adapt them to fulfil their protective role. 
which was repealed by Article 26 point 2 of the Act of 7 July 2016 amending the Act on departments of government administration and certain other acts (Journal of Laws of 2016, item 1250) - thus excluding the consideration of state defence needs in spatial planning in order to ensure conditions for defending the territory of the Republic of Poland, in particular by (Journal of Laws of 2004, No. 125, item 1309):

1) maintaining the defence potential of the state;

2) providing conditions for the functioning of the armed forces in peacetime and for action in the event of military aggression;

3) ensuring conditions for acceptance, deployment, supply and functioning of allied armed forces on the territory of the Republic of Poland;

4) ensuring the functioning of the state economy in the event of military aggression, including evacuation of the population and the material elements of the economy;

5) creation of conditions enabling localisation, implementation and adaptation of facilities and devices necessary for defence purposes.

In return, the legislator applied the provision enabling construction, performance and fulfilment of such needs as public purpose investments (Journal of Laws of 2016, item 2147, as amended). This does not solve the problem of taking into account the needs of state defence in spatial planning, but only gives the possibility of optional stating of the fact of implementation, and yet, in the military sector, construction or modernisation of the facilities themselves and of the installations located in them, takes place continuously. However, it should be noted that new solutions in the field of permanent and temporary fortification expansion are emerging (Szcześniak 2003, pp. 345-355).

In view of the above, it should be stated that the problem of security construction requires a systemic solution, taking into account technical, financial and legal requirements. It should also be stressed that within the Polish Armed Forces, there is a doctrine which places emphasis on engineering support in activities to aid infrastructure and to protect the army (DD-3.12(B) 2015).

Therefore, in the context of the discussion, it is justified to look at the current approach to the application of infrastructure solutions in the areas of military operations, especially in the defence context. This is where the so-called national infrastructure is secured and financed by a NATO member state, within the 
territory of that state, exclusively for the benefit of its own armed forces (including those assigned or appointed to NATO) (Pawłowski 2002, p. 44), which is an important defence element from the point of view of the Treaty.

It should be noted that in the reference books there is also a division into economic and military infrastructure (Table 1), where are both of strategic importance (DD-3.20 2010, p. 15).

\begin{tabular}{|c|c|}
\hline ECONOMIC INFRASTRUCTURE & MILITARY INFRASTRUCTURE \\
\hline 1) State defence management posts; & 1) Armed forces command posts; \\
\hline $\begin{array}{l}\text { 2) Government administration facilities crucial } \\
\text { for state defence; }\end{array}$ & 2) State air defence system components; \\
\hline $\begin{array}{l}\text { 3) Communications and Telecommunication } \\
\text { systems components regarding state } \\
\text { management; }\end{array}$ & 3) Integrated recon system components; \\
\hline 4) Material reserve bases and stockpiles; & $\begin{array}{l}\text { 4) Telecommunication, ITC and postal system } \\
\text { components used by the armed forces; }\end{array}$ \\
\hline 5) Food maintenance and processing facilities; & 5) Special-purpose military structures; \\
\hline $\begin{array}{l}\text { 6) Important facilities and devices: } \\
\text { a. transport; } \\
\text { b. hydro-technical; } \\
\text { c. power; }\end{array}$ & $\begin{array}{l}\text { 6) Facilities and devices of: } \\
\text { b. military ports; } \\
\text { c. road sections of strategic importance; } \\
\text { d. military airports; } \\
\text { e. barracks and stockpiles (material bases), } \\
\text { f. overhaul and manufacturing military } \\
\text { technology. }\end{array}$ \\
\hline $\begin{array}{l}\text { 7) Work, equipment manufacturing facilities } \\
\text { and materials for defence purposes; }\end{array}$ & \\
\hline 8) Important facilities and public devices & \\
\hline $\begin{array}{l}\text { 9) Facilities of Narodowy Bank Polski and Bank } \\
\text { Gospodarstwa Krajowego. }\end{array}$ & \\
\hline
\end{tabular}

Source: own study based on (DD-3.20 2010).

Table 1. Infrastructure of strategic importance

By limiting the concept of infrastructure to the area of military operations, one can come across a general name for military infrastructure (Günter 1986, p. 972). It is a component of the national infrastructure comprising all stationary facilities and devices, used directly and indirectly for defence of the country, which are constructed in compliance with the regulations applicable to the armed forces and the costs of which are included in the armed forces budget. The essential elements of this infrastructure include: 
- general-use military facilities (barracks, staff buildings, storage buildings, training, provisioning and service facilities, depots and warehouses, training grounds and exercise areas, military sea ports);

- public facilities of the national economy used by the army and including communication facilities (transport, communications, energy) (Juszczyk 2007, p. 110).

By its very nature, the aim of such infrastructure is to ensure the possibility of providing services to the defence subsystem of the state, one of the basic directions of which is to maintain constant readiness to effectively respond to threats to the independence and territorial integrity of the Republic of Poland. It does not fully exhaust the area related to the defence preparations of the state, but only constitutes a narrow element of the defence subsystem.

It is in the tasks performed within the framework of the defence preparations of the state by government administration bodies and local authority bodies that we will find the answer to the question as to what the defence infrastructure is (Pawłowski 2002, p.44). It is nothing more than, or as much as, infrastructure, which is a part of the state infrastructure, including permanent facilities and institutions necessary for the functioning of the state defence system, mainly created in peacetime and developed in times of threat and war. This was indicated in the material and financial undertakings in the scope of maintenance and improvement of non-military structures of the state defence system (Journal of Laws of 2004, No. 152, item 1599, as amended).

It ought to be remembered that it was in accordance with the defence planning that the manner of performing defence tasks by government administration bodies and local government bodies was determined, as well as the use of necessary means and resources for that purpose. In peacetime, defence tasks are carried out and determined, in the form of material and financial undertakings, in order to maintain and develop the defensive potential of the state and to prepare the armed forces, government administration bodies and local authority bodies to operate in conditions of external threat to state security and during war.

Looking for a clarification as to what is the defence infrastructure and what it is like, we are forced to look at the defence programmes they cover (Journal of Laws of 2004, No. 152, item 1599, as amended): 
1) requirements for non-military defence preparations;

2) material and financial undertakings in the area of maintenance and improvement of non-military structures of the state defence system, concerning:

a. preparation of the control system, including

- investments or construction, reconstruction, overhaul and equipping management posts with the equipment necessary to perform tasks in conditions of external threat to state security;

- defence communication systems;

b. satisfaction of the needs of the armed forces and the allied armed forces, including, inter alia, implementation by governmental and local authorities of

c. investments in and maintenance of defence-related roads, as well as preparation of means of transport for the armed forces and the allied armed forces;

- investments in railway lines of exclusively defensive significance and their maintenance, as well as maintaining the readiness of railway rolling stock and preparation of material and technical facilities to secure transport of the armed forces and the allied armed forces in accordance with the plans for technical protection of the railway network;

- investments in inland water roads for defence purposes;

- preparation of airport infrastructure for the armed forces and the allied armed forces;

- preparation of seaport infrastructure for the armed forces and the allied armed forces;

d. militarisation;

e. preparation of the protection of installations of particular importance for national security and defence,

3) directions of actions for the improvement and transformation of the citizen protection and civil protection systems for the ten-year period of the programme;

4) material and financial undertakings in the area of improvement of civil protection, concerning

a. management of civil protection, including, inter alia, investment, or construction, reconstruction, overhaul or providing the crisis management centres with the equipment necessary to perform crisis management tasks; 
b. civil protection formations;

c. collective and individual civil protection organisations, including:

- maintenance of buildings for protection,

- construction and maintenance of emergency drinking water intakes;

- population evacuation;

- emergency accommodation for the affected population;

- provision of sources of electricity and drinking water where the affected population is present;

- supply of energy and drinking water to designated food and pharmaceutical industry operators.

The above tasks do not constitute the full scope of tasks resulting from defence programming; they only indicate a fragment of them, used for representative purposes in order to present the problem of defence infrastructure. This only gives an idea of what facilities and devices can be considered as infrastructure of particular importance for the state's security and defence in accordance with the binding legal regulations.

As already indicated, one of the tasks of the state defence system is to prepare the management system, i.e. investment or construction, reconstruction, overhaul and providing the management posts with the equipment necessary to perform tasks in conditions of external threat to state security. Thus, it gives the impression that this is a key element of defence infrastructure. Nothing could be more misleading, because the legislator, intentionally or not, excluded them from the list of facilities that are particularly important for state security and defence (Journal of Laws 2003, No. 116, item 1090, as amended). Still, are these not the facilities that should be defended when under threat?

The legislator has clearly indicated that what is used for the purposes of the management posts are the general construction facilities and construction facilities provided with devices and equipment, the operation of which is independent from the generally available technical and utility infrastructure, later referred to as "special facilities" (Journal of Laws of 2004, No. 98, item 978).

It follows from the above that the infrastructure within the management posts consists of the posts and centres of management consisting of the technical facilities and devices necessary to ensure the efficient and safe functioning of 
the management bodies in the performance of their safety tasks. Whereas, the preparation of construction works, including special structures, for the needs of the functioning of particular authorities in a situation involving a threat to state security and during war, includes their selection, subsequent adaptation and, in special circumstances, their extension.

It should be pointed out that in normative acts, the legislator specified that the minister competent for construction, spatial planning and housing within the framework of arranging the management system:

1) prepares, on the basis of the concept of preparation and maintenance of special facilities, conditions which should be met by newly constructed special facilities and other facilities adapted to the needs of management posts;

2) prepares conditions for performance and acceptance of construction and assembly works as well as for performance of mechanical and technological commissioning;

3) plans, in consultation with the Minister of National Defence and the minister in charge of internal affairs, the standards for the receivables of material resources for the bodies operating in management posts, including the ones regarding accumulating and maintenance of the special reserve of these resources;

4) prepares, in accordance with the applications submitted by the bodies concerned, programmes for modernisation and construction of special facilities and submits them to the Council of Ministers for approval.

However, for formal reasons, these tasks cannot be carried out at national level. An attempt to issue the said conditions for performance and acceptance of construction and assembly works was refused on the grounds that there was no basis in the general regulations ${ }^{5}$. Firstly, the said conditions for performance and acceptance of construction and assembly works do not constitute technical conditions, as referred to in Articles 7 and 8 of the construction law. Secondly, there is no legislative delegation for general national regulation. The issuing of the said conditions by decrees or decisions of the minister in charge of construction, spatial planning and housing means they are only executed in his ministry.

5 The author participated in works over the said documents. 
The above gives rise to the thesis that the defence infrastructure is included in the list under the Regulation of the Council of Ministers of 24 June 2003 on facilities particularly important for the security and defence of the state and their special protection (Journal of Laws of 2003, No. 116, item 1090, as amended). The document states that the facilities of particular importance for the security and defence of the state, hereinafter referred to as "the facilities", are as follows:

facilities manufacturing, repairing or storing military arms and equipment, and combat assets, as well as facilities in which the research and development or construction works are conducted for the purposes of state security or defence;

state reserves warehouses, including liquid fuel, food, medicine and sanitary products storages;

1) facilities of organisational units subordinate to the Minister of National Defence or supervised by him;

2) facilities of car, railway, air, maritime and inland waterway transport, road, railroad engineering and communication infrastructure, as well as geodetic and cartographic documentation centres;

3) water dams and other hydro-technical devices;

4) facilities of organisational units of the Intelligence Agency;

5) facilities:

6) of Narodowy Bank Polski and Bank Gospodarstwa Krajowego;

7) of Polska Wytwórnia Papierów Wartościowych S.A. and Mennica Państwowa S.A.;

8) facilities where nuclear materials, radioactive sources and waste are manufactured, are used or stored;

9) telecommunication facilities intended for broadcasting of public radio and television programmes;

10) facilities of bodies and organisational units subordinate to the minister in charge of public administration or supervised by him;

11) facilities of bodies and organisational units subordinate to the minister in charge of internal affairs or supervised by him;

12) facilities of the organisational units of the Internal Security Agency;

13) facilities of the Police, the Border Guard and the State Fire Service;

14) facilities under the jurisdiction of the Minister of Justice, Prison Service and organisational units subordinate to or supervised by the Minister of Justice; 
15) establishments directly linked to the extraction of basic minerals;

16) facilities where materials presenting a particular explosive or fire hazard are manufactured, used or stored;

17) facilities conducting activities with the use toxic chemicals and their precursors, as well as biological, microbiological, microbial, toxic and other substances pathogenic to humans or animals;

18) power plants and other power facilities;

19) other facilities under the jurisdiction of government administration bodies, local authority bodies, formations, state institutions and entrepreneurs and other organisational units, the destruction or damage of which may pose a significant threat to life and health of people, national heritage and environment or cause serious material damage, as well as disrupt the functioning of the state.

However, this complete list of facilities has a certain caveat to it. It is the Council of Ministers that establishes the list of facilities considered particularly important for the security and defence of the state. At the same time, the legislator defined the tasks with respect to the facilities in question, indicating their category (\$3, Journal of Laws 2003, No. 116, item 1090) and the responsibility of the Minister of National Defence (\$7, Journal of Laws 2003, No. 116, item 1090) with respect to this matter.

Since the above list, which constitutesfacilities important for state security, partially overlaps with the list of critical infrastructure, does the defence infrastructure constitute both these lists? Nothing could be further from the truth. Therefore, in order to limit the issue and thus clarify the problem, it needs to be pointed out that the Minister of National Defence is responsible for excluding the critical infrastructure systems.

When listing the critical infrastructure and the first category facilities important for the state's security and defence, duplication of issues in terms of area and subject matter becomes evident (Table 2). Therefore, according to the author, the military and economic infrastructure of strategic importance, with no equivalents (duplication), are the facilities of defence infrastructure. For the sake of a clearer and more readable picture of the area under analysis, in order to combine these contents, it is indicated that the defence infrastructure is the: 
- facilities of organisational units subordinate to the Minister of National Defence or supervised by him;

- establishments manufacturing, repairing and storing military weapons and equipment and combat assets, as well as the ones in which research and development or construction work is carried out in the field of production for the purposes of state security and defence;

- facilities of the organisational units of the Intelligence Agency.

\begin{tabular}{|c|c|}
\hline $\begin{array}{l}\text { CRITICAL } \\
\text { INFRASTRUCTURE }\end{array}$ & $\begin{array}{l}\text { FIRST CATEGORY FACILITIES ESPECIALLY IMPORTANT } \\
\text { FOR STATE SECURITY AND DEFENCE }\end{array}$ \\
\hline \multicolumn{2}{|l|}{$\begin{array}{l}\text { a) providing energy, energy } \\
\text { production materials and } \\
\text { fuel; }\end{array}$} \\
\hline b) communications; & Communications infrastructure facilities; \\
\hline c) ITC networks; & $\begin{array}{l}\text { ITC facilities for broadcasting public radio and television } \\
\text { programmes; }\end{array}$ \\
\hline d) financial; & $\begin{array}{l}\text { belonging to Narodowy Bank Polski and Bank Gospodarstwa } \\
\text { Krajowego, } \\
\text { Polska Wytwórnia Papierów Wartościowych S.A. and Mennica } \\
\text { Państwowa S.A.; }\end{array}$ \\
\hline e) food supply; & $\begin{array}{l}\text { state reserves warehouses, including liquid fuel, food, medicine } \\
\text { and sanitary products storages; }\end{array}$ \\
\hline f) water supply; & water dams and other hydro-technical devices; \\
\hline \multicolumn{2}{|l|}{ g) health protection; } \\
\hline h) transport; & $\begin{array}{l}\text { facilities of car, railway, air, maritime and inland waterway } \\
\text { transport, road, railroad engineering and communication } \\
\text { infrastructure, as well as geodetic and cartographic } \\
\text { documentation centres }\end{array}$ \\
\hline \multicolumn{2}{|l|}{ i) rescue; } \\
\hline \multicolumn{2}{|l|}{$\begin{array}{l}\text { j) ensuring continuity of } \\
\text { public administration } \\
\text { activities }\end{array}$} \\
\hline \multirow[t]{4}{*}{$\begin{array}{l}\text { k) manufacturing, stockpiling, } \\
\text { storage and use of chemical } \\
\text { and radioactive substances, } \\
\text { including hazardous } \\
\text { substances pipelines; }\end{array}$} & $\begin{array}{l}\text { facilities where nuclear materials, radioactive sources and waste } \\
\text { are manufactured, used or stored; }\end{array}$ \\
\hline & $\begin{array}{l}\text { facilities manufacturing, repairing or storing military arms and } \\
\text { equipment, and combat assets, as well as facilities in which the } \\
\text { research and development or construction works are conducted } \\
\text { for the purposes of state security or defence }\end{array}$ \\
\hline & $\begin{array}{l}\text { facilities of organisational units subordinate to the Minister of } \\
\text { National Defence or supervised by him }\end{array}$ \\
\hline & facilities of organisational units of the Intelligence Agency; \\
\hline
\end{tabular}

Source: Own study.

Table 2. The list of critical infrastructure and the first category facilities especially important for the state security and defence 
It is precisely these facilities for which the Minister of National Defence is responsible under the indicated Regulation that should be referred to as defence infrastructure. This is in line with both the list in question and the terminology used $^{6}$.

This is the terminology used in doctrinal documents issued by the Chief of the General Staff of the Polish Armed Forces (DD-3.20 2010, p.14), where it was indicated that the defence infrastructure of the state includes:

1) facilities and devices of economic infrastructure of strategic importance, crucial for the efficient functioning of the state, including the armed forces, at the disposal of and administered by civil institutions;

2) military infrastructure facilities of strategic importance for national security and of key importance for the success of military operations.

Here, we can see the extremely important role of defence infrastructure as a means of ensuring security and the proper functioning of the state. Therefore, bearing in mind only those elements of infrastructure which are essential for the proper functioning of the state, crucial for the broadly understood security and necessary for the national economy, it is justified to call it the defence or to assign it with a strategic character.

\section{Conclusion}

The currently functioning safety system, subjected to the analysis, is flawed and incomplete. It is a product of many aspects, which in the new reality have created many challenges for the state. It was these changes in the functioning of the state, its decentralisation, and the free market economy that led to the lack of a coherent concept to guide the implementation of tasks related to security and the lack of a legislative definition of the functioning of this system.

Safety is too important a task to allow for it not to be comprehended. Tasks in the field of state security and defence are not limited solely to the powers of the

6 Defence, i.e. subject to protection. 
Minister of National Defence. In this system, therefore, everyone should speak the same language, giving concepts the same meaning.

However, the mere explanation (identification) of the notion of defence infrastructure does not yet give a view that would allow us to understand the essence of infrastructure of a strategic nature, particularly important for the security and defence of the state. When referring to infrastructure as defensive, it should be borne in mind that any irregularities in its functioning, as well as damage or destruction of its accompanying components, may cause serious disturbances in the functioning of the defence system of the state, including the facilities for which the Minister of National Defence is responsible.

The current sectoral legislation adopts a war-peace time division of threats, which directly affects the functioning of the existing security system, but does not make a distinction into critical, civil-defence or military infrastructures. Thus it leads to unnecessary duplication of structures ensuring security in times of political and military threats and peace. After all, defence infrastructure is one of the most important components of the defence system of the state and constitutes an important element of the proper functioning of the state at a time of threat to its security, prepared in times of peace.

According to the author, defence infrastructure has been partly identified and defined, but is it an effective and unambiguous delineation, is it a correct interpretation? It is invariable that infrastructure may be called defensive, or considered strategic, if it is identified as infrastructure which includes key systems for the security of the state, its citizens and of fundamental importance for the functioning of the economy, serving to ensure the efficient functioning of public administration bodies, as well as institutions and entrepreneurs included in this system.

When calling this part of the state's infrastructure the defence infrastructure, it is necessary to clarify that the essence of security (and not defence) of such infrastructure is to ensure its continuity of operation and the possibility of its reconstruction in the event of damage or destruction - because only then can the continuity of the state's functioning be ensured. Thus, according to the author, the part of state infrastructure that includes fixed facilities and devices and institutions necessary to ensure the continuity of state functioning in various 
stages of national security threat can be called the defence infrastructure, and the essence of the security of this infrastructure is to ensure the continuity of its functioning and swift reconstruction in the event of its damage or destruction.

However, the problem lies not in the nomenclature of infrastructure, but in bringing order to legal acts related to the very part of the state infrastructure which is of key importance for the security and defence of the state, for its undisturbed functioning. Security here is understood as "the state of no threat, peace" (Arnold 2008, p.49), as "the certainty of the existence, possession, functioning and development of an entity. Certainty is not only the result of risks absence (nonoccurrence or elimination), but it is also the result of creative activity by a given entity and is variable in time, i.e. it has the nature of a social process"' (Zięba Zając 2010, p. 4).

\section{References}

AAP-6, 2014. Słownik terminów i definicji NATO. [online] Available from: http://wcnjk. wp.mil.pl/plik/file/N_20130808_AAP6PL.pdf [Accessed 8 Jul 2018].

Arnold A., 2008. Stownik języka polskiego. Wydawnictwo Naukowe PWN, Warsaw, Atlas I.R., 2008. 21st Century Security and CPTED. Designing for Critical Infrastructure Protection and Crime Prevention. CRC Press, London-New York.

BBN, 2014. Biała Księga Bezpieczeństwa Narodowego Rzeczypospolitej Polskiej 2014. [online] Available from: http://www.spbn.gov.pl/download/4/13631/Biala_Ksiega_ inter_mm.pdf [Accessed 08.07.2018].

BBN, 2014. Strategia Bezpieczeństwa Narodowego Rzeczypospolitej Polskiej 2014. [online] Available from: https://www.bbn.gov.pl/ftp/SBN\%20RP.pdf [Accessed 8 Jul 2018].

Czerni S., 1984. Leksykon naukowo-techniczny. Wydawnictwo Naukowo-Techniczne, Warsaw.

DD-3.12 (B), 2015. Wsparcie inżynieryjne w operacjach połączonych. Szt. Gen. sygn. $922 / 2015$, Warsaw.

DD-3.20, 2010. Maskowanie wojsk i wojskowej infrastruktury obronnej. Szt. Gen. sygn. 1629/2010, Warsaw.

Dunaj B. (ed), 1996. Stownik wspótczesnego języka polskiego. Wilga, Warsaw.

Dziubińska-Wójcik K. (ed), 2016. Leksykon Bezpieczeństwa. Jan Kochanowski University, Kielce.

Günter K., 1986. Handbuch zur Ökonomie der Verteidigungspolitik. Walhalla u. Praetoria Verlag, Regensburg. 
Jakubczak R. (ed), 2003. Obrona narodowa w tworzeniu bezpieczeństwa III RP. Bellona, Warsaw.

Jakubczak R., Flis J., (eds), 2006. Bezpieczeństwo Narodowe Polski w XXI wieku. Bellona, Warsaw.

Jankowski J., 2006. Ochrona i obrona obiektów i zwalczanie dywersji przez siły OT w obszarach zabudowanych. In G. Sobolewski (ed), Rola terenu zurbanizowanego we wspótczesnych operacjach, AON, Warsaw.

Juszczyk M., 2007. Infrastruktura logistyczna wojskowej jednostki budżetowej. In Logistyka i ekonomika bezpieczeństwa - wspótczesne dylematy, Materiał z seminarium naukowego. Zeszyty Naukowe AON nr 2(67)A;

Kaczmarski M., 2010. Bezpieczeństwo energetyczne Unii Europejskiej. Wydawnictwa Akademickie i Profesjonalne, Warsaw.

Kitler W., 2002. Obrona narodowa III RP. Pojęcie. Organizacja. System, Zeszyty Naukowe AON Warsaw.

Lesław A., 1974. Mała encyklopedia ekonomiczna, Państwowe Wydawnictwo Ekonomiczne, Warsaw.

Maliński W., Kwiatkowski P., 2011. Stan budownictwa ochronnego w Polsce. XXV Międzynarodowa Konferencja Naukowo-Techniczna „EKOMILITARIS-2011”, Zakopane, 13-16.09.2011. Wyd. WAT, Warsaw.

Obwieszczenie Marszałka Sejmu Rzeczypospolitej Polskiej z dnia 13 maja 2016 r. w sprawie ogłoszenia jednolitego tekstu ustawy o planowaniu i zagospodarowaniu przestrzennym (Dz. U. z 2016 r. poz. 778.) [online] Available from: http://prawo.sejm. gov.pl/isap.nsf/DocDetails.xsp?id=WDU20160000778 [Accessed 9 Jul 2018].

Rozporządzenie Rady Ministrów z dnia 28 września 1993 r. w sprawie obrony cywilnej. (Dz. U. z 1993 r. nr 93, poz. 429.). [online] Available from: http://prawo.sejm.gov.pl/ isap.nsf/DocDetails.xsp?id=WDU19930930429 [Accessed 9 Jul 2018].

Rozporządzenie Rady Ministrów z dnia 25 czerwca 2002 r. w sprawie szczegółowego zakresu działania Szefa Obrony Cywilnej Kraju, szefów obrony cywilnej województw, powiatów i gmin. (Dz. U. z 2002 r. nr 96, poz. 850.) [online] Available from: http://prawo.sejm.gov. pl/isap.nsf/DocDetails.xsp?id=WDU20020960850 [Accessed 9 Jul 2018].

Rozporządzenie Rady Ministrów z dnia 24 czerwca 2003 r. w sprawie obiektów szczególnie ważnych dla bezpieczeństwa i obronności państwa oraz ich szczególnej ochrony. (Dz. U. z 2003 r. nr 116 poz. 1090 ze zm.) [online] Available from: http://prawo.sejm. gov.pl/isap.nsf/DocDetails.xsp?id=WDU20031161090 [Accessed 9 Jul 2018].

Rozporządzenie Rady Ministrów z dnia 27 kwietnia 2004 r. w sprawie przygotowania systemu kierowania bezpieczeństwem narodowym. (Dz. U. z 2004 r. nr 98 poz. 978.) [online] Available from: http://prawo.sejm.gov.pl/isap.nsf/DocDetails. xsp?id=WDU20040980978 [Accessed 9 Jul 2018].

Rozporządzenie Ministra Infrastruktury z dnia 7 maja 2004 r. w sprawie sposobu uwzględniania w zagospodarowaniu przestrzennym potrzeb obronności 
i bezpieczeństwa państwa. (Dz. U. z 2004 r. nr 125, poz. 1309. [online] Available from: http://prawo.sejm.gov.pl/isap.nsf/DocDetails.xsp?id=WDU20041251309 [Accessed 9 Jul 2018].

Rozporządzenie Rady Ministrów z dnia 15 czerwca 2004 r. w sprawie warunków i trybu planowania i finansowania zadań wykonywanych w ramach przygotowań obronnych państwa przez organy administracji rządowej i organy samorządu terytorialnego. (Dz. U. z 2004 r. nr 152 poz. 1599 ze zm.) [online] Available from: http://prawo.sejm. gov.pl/isap.nsf/DocDetails.xsp?id=WDU20041521599 [Accessed 9 Jul 2018].

Rozporządzenie Rady Ministrów z dnia 24 sierpnia 2004 r. w sprawie określenia rodzajów nieruchomości uznawanych za niezbędne na cele obronności i bezpieczeństwa państwa. (Dz. U. z 2004 r. nr 207, poz. 2107. ze zm.) [online] Available from: http://prawo.sejm. gov.pl/isap.nsf/DocDetails.xsp?id=WDU20042072107 [Accessed 9 Jul 2018].

Pawłowski J., 2002. Słownik terminów z zakresu bezpieczeństwa narodowego. AON, Warsaw.

Pawłowski J., 2009. Słownik terminów z zakresu bezpieczeństwa narodowego. AON, Warsaw.

Radziejewski R.,2013. Infrastruktura a bezpieczeństwo, Zeszyty Naukowe AON 3(92).

Stańczyk J., 1996. Wspótczesne pojmowanie bezpieczeństwa. Inst. Studiów Politycznych PAN, Warsaw.

Szcześniak Z., 2003. Rozwiązania schronowe jako element inżynierii bezpieczeństwa w zadaniach ochrony ludności i obrony cywilnej. XVII Krajowa Konferencja NaukowoTechniczna „EKOMILITARIS-2003”, Zakopane, 3-5.09.2003. Wyd. WAT, Warsaw.

Ustawa z dnia 7 lipca 1994 r. - Prawo budowlane. (Dz. U. z 1994 r. nr 89 poz. 414 ze zm.) [online] Available from: http://prawo.sejm.gov.pl/isap.nsf/DocDetails. xsp?id=WDU19940890414 [Accessed 9 Jul 2018].

Ustawa z dnia 21 sierpnia 1997 r. o gospodarce nieruchomościami. (Dz. U. z 2016 r. poz. 2147 ze zm.) [online] Available from: http://prawo.sejm.gov.pl/isap.nsf/DocDetails. xsp?id=WDU19971150741\&type $=2$ [Accessed 9 Jul 2018].

Ustawa z dnia 22 sierpnia 1997 r. o ochronie osób i mienia. (Dz. U. z 2007 r nr 114, poz. 740. ze zm.) [online] Available from: http://prawo.sejm.gov.pl/isap.nsf/DocDetails. xsp?id=WDU19971140740 [Accessed 9 Jul 2018].

Ustawa z dnia 26 kwietnia 2007 r. o zarządzaniu kryzysowym. (Dz. U. z 2007 r. nr 89, poz. $590 \mathrm{ze} z \mathrm{zm}$.) [online] Available from: http://prawo.sejm.gov.pl/isap.nsf/DocDetails. xsp?id=WDU20070890590 [Accessed 9 Jul 2018].

Ustawa z dnia 7 lipca 2016 r. o zmianie ustawy o działach administracji rządowej oraz niektórych innych ustaw. (Dz. U. z 2016 r. poz. 1250.) [online] Available from: http:// prawo.sejm.gov.pl/isap.nsf/DocDetails.xsp?id=WDU20160001250 [Accessed 9 Jul 2018].

Wiśniewski B., 2006. Zasadnicze problemy realizacji zadań obronnych resortu spraw wewnętrznych i administracji. MSWiA, Warsaw. 
Wojewódzka-Król K. (ed), 1999. Rozwój infrastruktury transportu. Wydawnictwo Uniwersytetu Gdańskiego, Gdańsk.

Wojnarowski J., 2013. System obronny Rzeczypospolitej Polskiej. AON, Warsaw.

Zięba R., Zając J., 2010. Budowa zintegrowanego systemu bezpieczeństwa narodowego Polski, [online] Available from: http://www.mrr.gov.pl/rozwoj_regionalny/ Polityka_rozwoju/SRK/Ekspertyzy_aktualizacja_SRK_1010/Documents/budowa_ zintegrowanego_systemu_bezpieczenstwa_narodowego_Polski_ekspertyza_2010. pdf. [Accessed 10 Jul 2018]. 